\title{
The Use of a Zone Model in Fire Engineering Application
}

\author{
STAFFAN BENGTSON
}

The Swedish Fire Protection Association, Sweden

BENGT HÄGGLUND

National Defence Research Institute, Sweden

\section{SUMMARY}

In this paper is shown the possibility to modernize fire protection engineering in a way that it will be on the same level as other parts of the design of a building. A fire simulation model will be presented shortly. The model predicts the time for smoke-logging, flash-over and detection events for a given geometry of the building. The input parameter is the fire growth curve. In a special section it is shown how the fire growth can be predicted. Sometimes the fire area is known, but more often statistical Information has to be used. Finally some engineering applications are indicated, where the consequences of a fire in a bus garage and a textile factory are discussed.

\section{INTRODUCTION}

During the last few decades extensive efforts have been made to create analytical models by which it is possible to judge the safety level objectively. There are three main reasons for this interest:

a) As the costs of fire safety measures are increasing the cost effectiveness is of great interest.

b) Architects and consulting engineers have found that rigid praxis, Inflexible bullding codes and insurance recommendations very often are a hindrance to an effective design of a building.

c) By quantitative analyzis you wish to obtain information on the effectiveness of new types of measure systems without waiting for experience from real fires.

In spite of the fact that there now exist analytical models to describe a fire and the threat from it, few attempts have been made to use them as an engineering tool. In the following will be demonstrated how it is possible with the knowledge of today to predict with good accuracy the threat from fire and the effect of various fire safety measures. Similar analyzis have been made by Bengtson, Hägglund and Ramachandran (1-5).

\section{THE SIMULATION MODEL}

The threat from fire is calculated by a zone model which is described in (6). Its physical outlay is described in Figure 1. The enclosure is divided into two homogeneous layers, a layer next to the celling which contains the hot combustion products and one next to the floor which con- 
MASS FLOW:

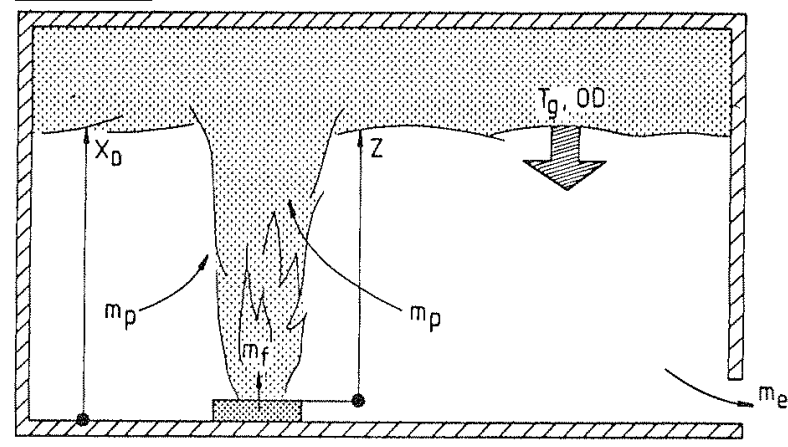

HEAT FLOW:

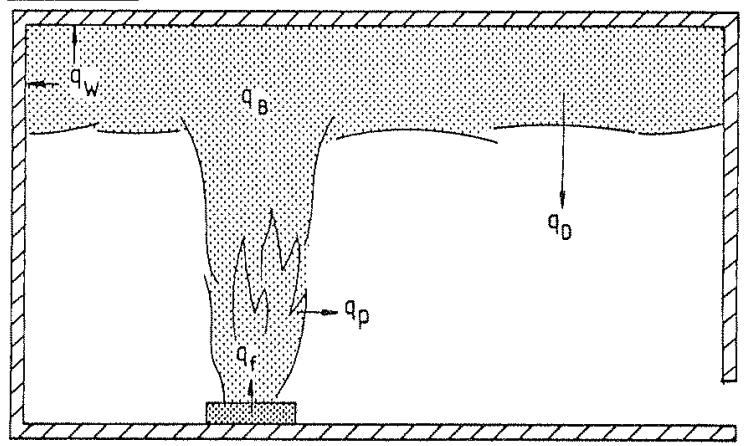

Figure 1. The smoke filling simulation model

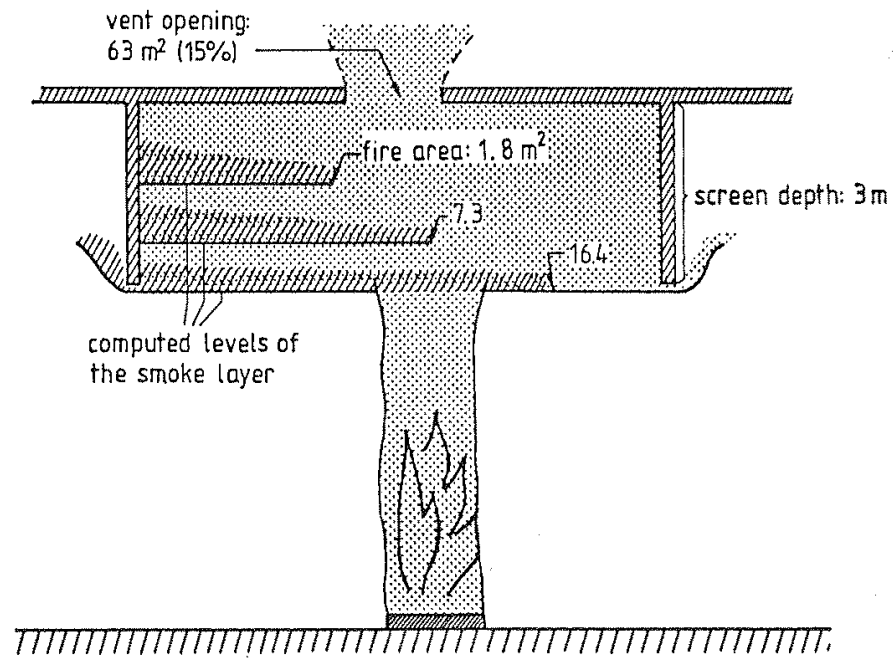

Figure 2. Computed levels of the smoke layer for kerosene fires of area $1.8,7.3$ and $16.4 \mathrm{~m}^{2}$. 
tains fresh air. The interface moves down at a velocity determined by the rate of air entrained into the fire plume ( $m_{n}$ ) and by the rate of mass flow through leaks close to the floor ( $m_{e}$ ). P By means of a mass balance for the lower cool region it is possible to calculate this drop veloctty.

The burning 1 tem releases heat at a rate $q_{f}$. The heat is lost by radiation and convection to the enclosing structures of the upper gas layer $\left(q_{\mathrm{w}}\right)$. The upper layer also loses heat by radiation to the lower cool region of the enclosure $\left(q_{p}\right)$. Other loss terms are the radiant heat from the fire plume $\left(q_{p}\right)$ and the heat to rise the temperature of the upper layer $\left(q_{B}\right)$. By means of a heat balance for the upper gas layer, including the fire plume, the temperature of the descending smoke layer is computed.

In addition to the closed-single-space model, a model which accounts for roof-venting is inserted into the model. For given values of the vent area and the depth of screens, extending downwards from the celling, the model predicts the depth and temperature of the smoke layer.

\section{COMPARISON WITH EXPERIMENTAL FIRES}

In the following is shown the agreement between calculated results and the measured data from two experimental series with roof-venting.

In the first series, experimental fires were conducted in a central test cell of an afrcraft hangar (7). The floor area of the test cell was $20 \times 21$ meters and the height approximately 15 meters. Trays of aviation kerosene were burnt with the areas of $1.8,7.3$ and $16,4 \mathrm{~m}^{2}$. The duration of the steady-state burning was 3-4 minutes and the 11 near burning rate was approximately $4 \mathrm{~mm} / \mathrm{min}$. The effective discharge area of the vents was $1.125 \%$, $4.5 \%$ or $9 \%$ of the floor area. The depth of the screens was $0,1.5$ or 3 meters.

Figures 2 and 3 display the results of the model in comparison with the measured data. In Figure 2 the computed levels of the smoke layer are displayed for the roof vent of the largest area $\left(63 \mathrm{~m}^{2}\right)$ and the screen depth of 3 meter. For the biggest fire $\left(16.4 \mathrm{~m}^{2}\right)$ the computed layer thickness was a.few $\mathrm{cm}$ below the screens. The result agrees well with what 1 s stated from the experimental observations: "In the experiments fnvolving the greatest outlet venting and the 3-m draught curtains very 1ittle spillover of smoke into the roof beyond the test celloccurred". Figure 3 shows the average values of the measured temperature rise of the hot gases below the roof in the test cell as a function of fire size and the distance below the roof - and for all combinations of the test variables in the experimental series. The computed values - based on an upper homogeneous and isothermal zone are in good agreement with the measured data. The distribution of the f11led points in the figure refers to different test conditions.

In the second series, experimental fires were conducted in an industrial building ( 8 ). The floor area of the building was $1000 \mathrm{~m}^{2}$ and the height 9.5 meter. Various numbers of wood cribs were burnt and various areas of fire ventilation were avaliable. In Figure 4 the computed height of the smoke layer from one experiment is compared with the one observed. The agreement is fairly good.

\section{THE DESIGN FIRE}

The design fire can elther be described by the horizontal fire area or the heat output as a function of time. The scenario can be chosen in at least 


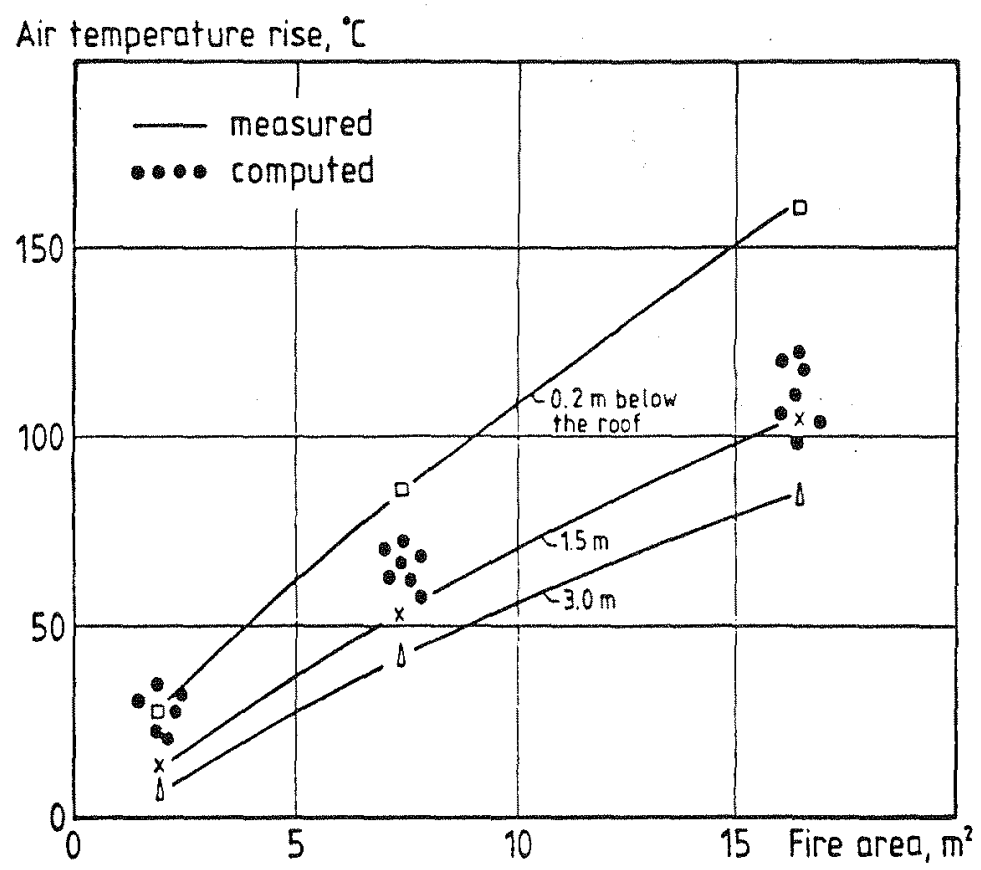

Figure 3. Measured and computed values of the temperatures near the ceiling for kerosene fires of area $1.8,7.3$ and $16.4 \mathrm{~m}^{2}$.

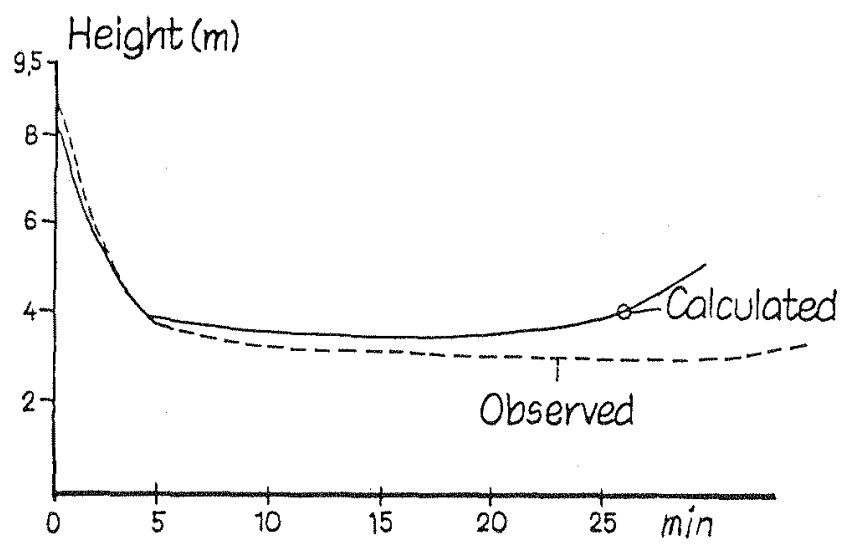

Figure 4. Measured and computed values of the smoke layer for a wood crib fire in an industrial building 
four different ways:
a) Known fire area
b) Experiences from fire tests
c) Experiences from real fires using sprinkler statistics
d) Experlences from real fires using statistical information on fire area

\subsection{Known fire area}

Very seldom the fire area is exactly known. An exception may be, however, if the expected fire will be in an oil tray or a similar object, or in a container for refuse. Experiences from fires with only one burning item can also be used, which may be the case in a bus garage, for example, where you know depending on how the fire is expected to start and on the material Inside the bus - when the bus windows are breaking and the whole bus is burning. You also have a good knowledge of how long it will take before the next bus catches fire.

\subsection{Experiences from fire tests}

Hägglund has used information from tests at the Factory Mutual laboratories to predict the fire growth as a function of time (2). The fire growth was assumed to be an exponential function of time obtained in a series of fullscale tests (9). Doubling times between 1 and 5 minutes were reported which can be representative of stored goods under similar conditions like for instance in the tests. Bengtson and Hägglund have in (3) used data on burning furntture items to predict the times for smoke-filling and temperatures in single enclosures like patient rooms, assembly halls and atrfum buildings.

\subsection{Experiences from real fires using sprinkler statistics}

This method has been used by Bengtson in (1) and in the preliminary work for the Swedish Fire Ventilation Design Guide (10). The fire area in these works has been related to the hazard groups as defined in the sprinkler regulation. This has been done by using information from fires where sprinklers have operated. In (10) the fire area at operation time was assumed to be the same as the sprinkler area in the hazard group. It is evident, however, that it is a mistake to give the same value of the fire area as the sprinkler area at operation time for sprinklers. Bengtson therefore made some modifications of the fire growth rates as presented in (1). As there were some rough assumptions which had to be made a cooperation between the Swedish Fire Protection Association and the Fire Research Station was Initiated to develop better fire growth models. This work is presented below.

\subsection{Experiences from real fires using statistical information on fire area}

In United kingdom information is collected from almost any fire to which the fire brigade is called. The information can be analyzed in different ways. The area damaged after ignition is reported, for example, and also the time period between an estimated fire-start and the control of the fire. The number of jets is also reported. All information is categorized depending on the activity in the building. For the various groups the information can be related to where the fire started: production areas, storage areas and "other" areas. The statistical information, which is gathered and administered by the Fire Research Station, has been used for various applications $(4-5)$. 


\section{ENGINEERING APPLICATIONS}

Computer-based analyzis by the model in the solution of two fire protection engineering problems is demonstrated below. The consequences of a fire in a bus garage and in a textile factory are discussed.

\subsection{Bus fire in a garage}

In the garages for the transportation companies there are many buses parked during the night, which means that a fire can produce extensive communication problems for the passengers the day after a fire. The question has therefore been raised how to protect the buses against fire. For this engineering work the simulation model presented in this paper has been used.

In Figure 5 the calculated smoke-filling times are presented for a garage with floor area of $4000 \mathrm{~m}^{2}$ and of a height of 5 meters. Also the temperatures of the smoke layer are displayed in the figure. The calculations are based on two heat output scenarios, 20 and $40 \mathrm{MW}$. $20 \mathrm{MW}$ corresponds to one bus burning and $40 \mathrm{MW}$ to two buses burning. The time given in the figure is the time after flash-over of the bus. Flash-over of the bus is assumed to occur 10 minutes after the fire start. At that stage the bus windows collapse and smoke and hot gases flow out into the garage. That means that the heat output is zerountil 10 minutes after the fire starts and then grows to $20 \mathrm{MW}$. The fire area is constant until the next bus, which is parked close to the first one, is ignited, which will take only 2-3 minutes.

As can be noticed from the figure the garage - with one bus burning - can be smoke-filled down to the level of 3 meter about 15 minutes after the fire starts in the bus. The temperatur of the smoke layer at that time is about $150^{\circ} \mathrm{C}$.

The consequences of the fire.

If sprinkler is installed, the first bus will be totally damaged, the neighbourlng buses probably only damaged by heat and perhaps $10-20$ buses only damaged by smoke.

If there is no sprinkler system installed or if 1 t is out of work the flre brigade must check the fire. To give them any chance at all a fire detection system must be installed.

If the attendance time is 10 minutes this means that the fire brigade can start fighting the fire about 21 minutes after the fire start. Flash-over in the garage has not yet occurred but the smoke is down to $1.5-2 \mathrm{~m}$ from the floor and at least 2 buses are burning. This means that the fire is extremely difficult to fight, especially as there are only 0,5 meters between the buses, which makes it impossible to send in any fire men. A total damage is a probable result. If a fire ventilation system correctly designed, is provided together with a fire detection system fire fighting may be possible and the result will be that only 2 buses axe damaged.

\subsection{Fire in a textile factory}

Data on fire areas from textile factories were used as input in the fire simulation model. As the statistics give you the area damaged after the fire is extingutshed, but the equation for fire growth describes the fire size at a specific time, you probably get some exaggeration of the threat. It is not certain that the whole area is burning at the same time. In future works this problem must be analyzed. The rate of fire growth presented in (4) was used, defined by eq 1 


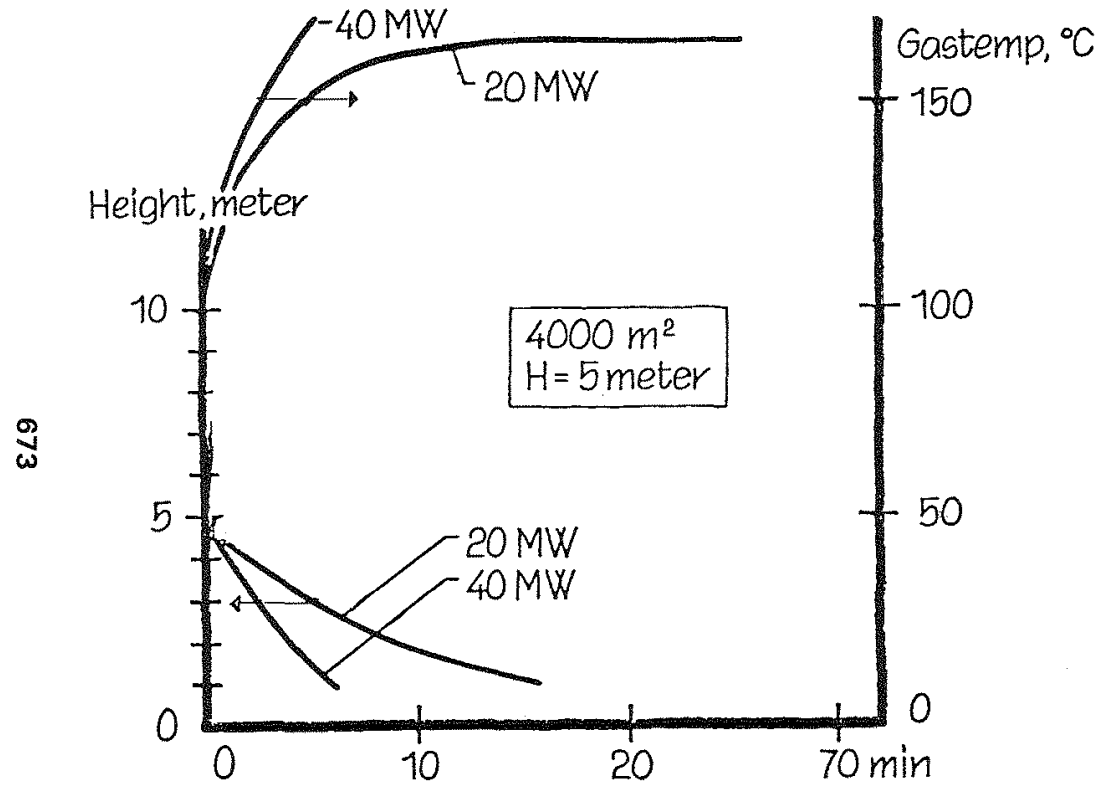

Figure 5. Computed values of the smoke layer and temperature for a bus fire in a garage

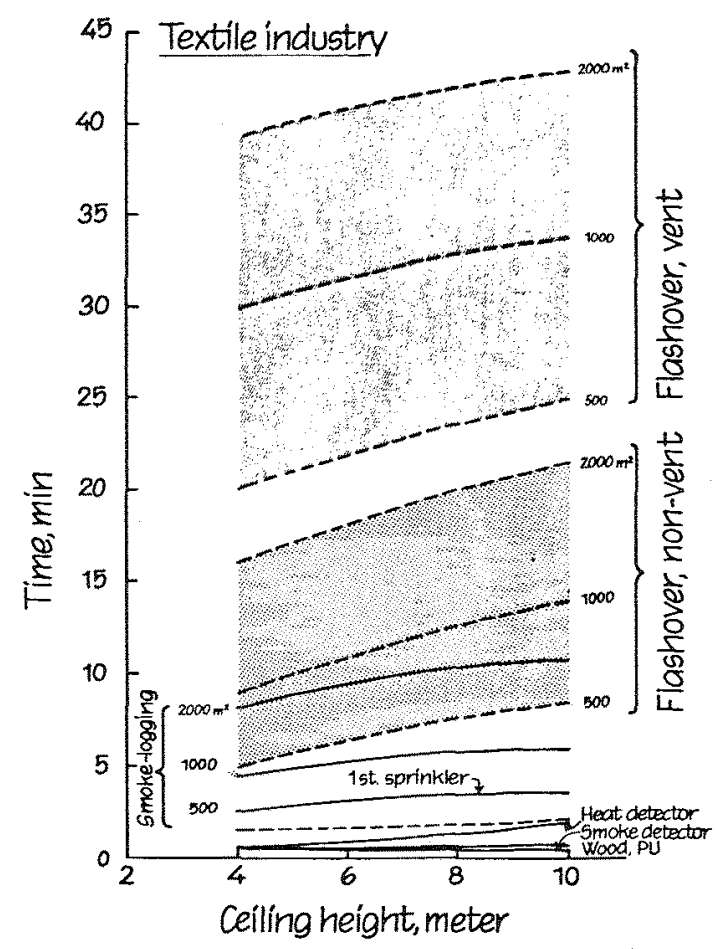

Figure 6. Flashover time, smoke filling and detection events in a textile industry 


$$
A=4.7 \cdot e^{0.063 \cdot t}
$$

where $A$ denotes the area damaged in $t$ minutes. The calculated result is presented in Figure 6 for single enclosures of various sizes and ventilation conditions. The floor area ranges from 500 to $2000 \mathrm{~m}^{2}$ and the ceiling height from 4 to 10 meters. Two ventilation conditions are considered, NON-VENT and VENT. Under the ventilation condition NON-VENT the enclosure is assumed to be closed except for openings close to the floor. Under the ventilation condition VENT vents are assumed to be opened in the roof.

The critical events when smoke-logging and flash-over occur in the single enlosures are denoted by SMOK-LOGGING and FLASH-OVER In the figure. Flashover is assumed to occur when the computed gas temperature for the entire volume reaches $300{ }^{\circ} \mathrm{C}$ as an average. The detection events are denoted by SPRINKIER, HEAT DETECTOR and SMOKE DETECTOR - representing the time when the first sprinkler, heat and smoke detector will operate. The sprinklerhead is assumed to be located.2.5 meters from the plume axis of the fire and the heat and smoke detector 4 and 7 meters, respectlvely, from the axis. The criteria of the events are based on works by Alpert (11) and by Heskestad and Dellchatsios (12).

The number of hose reel-jets reported to Fire Research Station which must be used to fight the fire may be related to the fire area, eq 2

$$
\text { nojet }=4 \cdot \ln \mathrm{A}_{\mathrm{F}}+2.71
$$

When giving this correlation it is expected that 5 hose-reel-jets correspond to 1 main-jet. The equation is valid for production areas.

Comments on the computed results will be given at the presentation of this paper.

\section{FUTURE WORK}

In the future the theorles presented in this paper have to be verified in varfous ways. The rates of fire growth for varlous industrial groups should be determined to be used as input in analytical models. The rate of fire growth at the beginning of the fire should be studied in more detall as $1 t$ has a great influence especially on the detection times for heat and smoke detectors. The computed results and predictions should be compared with real fires as regards, for example, detection events and observed times to flash-over.

\section{REFERENCES}

1. Bengtson, S., The effect of different protection measures with regard to fire damage and personal safety. FoU-Brand (1978):1

2. Hägglund, B., Hazardous conditions in single enclosures subjected to f1re, a parameter study. Stockholm: FOA C 20524-D6. Dec. 1983

3. Hägglund, B \& Bengtson, S., A smoke filling simulation model and 1ts engineering applications. To be published in Fire Technology, 1985

4. Ramachandran, G., Economic value of automatic flre detectors. Borehamwood: Bullding Research Establishment. BRE IP 27/80, 1980

5. Ramachandran, G., Exponentlal model of. fire growth. The First International Symposium on Fire Safety Sclence. Gaithersburg, Md, USA, October 1985 
6. Hägglund, B., Simulating the smoke filling in single enclosures. Stockholm: FOA C 20513-D6. 1983

7. Keough, J J, Venting fires through roofs, (Experimental fires in an aircraft hangar). Chatswood, Australia: Commonwealth Experimental Bullding Station. Report 344. 1972

8. Kruppa, J \& Lamboley, G, Contribution a l'etude des incendies dans les batiments de grand volume realises en construction metallique. Centre Technique Industriel de la Construction Metallique. September 1983.

9. Friedman, R., Quantification of threat from a rapidly growing fire in terms of relative material properties. Fire and Materials $2(1978): 7$

10. Brandventilation för industri- och lagerbyggnader. Sthlm: SBF. SBFs rekommendationer 5:3 1982

11. Alpert, $R$ L, Calculation of response time of ceiling-mounted fire detectors. Fire technology 8(1972):3, pp $181 \mathrm{ff}$.

12. Heskestad, $G \&$ Delichatsios, $M A$, Environments of fire detectors phase I: Effect of fire size, ceiling height and materfals, Vol. 2. Analyzis. Wash., D.C.: Nat1 Bur of Stand. (Factory Mutual Research Corp). NBS-GCR-77-95. 1977 
